\title{
Prototype Penghitung Jumlah Pengunjung Yang Berada Di Dalam Kebun Binatang Berbasis Mikrokontroler
}

\author{
Adi Chandranata ${ }^{1}$, Albar $^{2}$, Ibnu Sutowo Ahmad ${ }^{3}$ \\ ${ }^{123}$ Jurusan Teknik Elektro Politeknik Negeri Padang \\ adichandra@pnp.ac.id \\ Kampus Politeknik Negeri Padang, Limau Manis Padang
}

\begin{abstract}
This tool works to alleviate the duties of zoo officers. This tool can also prevent errors in counting the number of visitors that are often done by humans. This tool is able to count visitors in and out as well as those inside the zoo displayed on one LCD. The number of visitors is limited to 999. The visitor counters automatically count the number of visitors entering and leaving the zoo. Photodioda 1 and touch sensor 1 serve to count visitors entering the zoo. Photodioda 2 and touch sensor 2 function to count visitors coming out of the zoo. The appearance of the number of visitors entering and exiting will be displayed on the $2 \times 16$ LCD. All sensors and appearance are processed by a microcontroller. To calculate the number of visitors who are still inside the zoo, the formula is "the number of visitors in and out of visitors", the number of visitors in the zoo will also be displayed with $2 \times 16 \mathrm{LCD}$. Of all the error tests that occur are $0 \%$ or no errors occur during testing. By using $2 \times 16$ LCD, the display for the number of visitors entering and exiting is limited, which is only up to 999 people.
\end{abstract}

Keywords: Photodioda, Touch Sensor (Touch), Microcontroller

\begin{abstract}
Abstrak - Alat ini bekerja untuk meringankan tugas dari petugas kebun binatang. Alat ini juga dapat mencegah kesalahan dalam penghitungan jumlah pengunjung yang sering dilakukan oleh manusia. Alat ini mampu menghitung pengunjung masuk dan keluar serta yang berada di dalam kebun binatang dengan ditampilkan pada satu LCD. Tampilan penghitungan jumlah pengunjung terbatas hanya sampai 999. Alat penghitung jumlah pengunjung ini bekerja secara otomatis menghitung jumlah pengunjung yang masuk dan keluar dari kebun binatang. Photodioda 1 dan sensor sentuh 1 berfungsi untuk menghitung pengunjung yang memasuki kebun binatang. Photodioda 2 dan sensor sentuh 2 berfungsi untuk menghitung pengunjung yang keluar dari kebun binatang. Penampilan jumlah pengunjung yang masuk serta keluar akan di tampilkan pada LCD $2 \times 16$. Semua sensor dan penampilan di proses oleh mikrokontroller. Untuk menghitung jumlah pengunjung yang masih berada di dalam kebun binatang digunakan rumus "jumlah pengunjung masuk-jumlah pengunjung keluar", jumlah pengunjung yang berada di dalam kebun binatang juga akan ditampilkan dengan LCD 2x16. Dari semua pengujian eror yang terjadi adalah $0 \%$ atau tidak terjadi eror selama pengujian. Dengan menggunakan LCD 2x16 maka tampilan untuk jumlah pengunjung yang masuk dan keluar terbatas, yaitu hanya sampai 999 orang.
\end{abstract}

Kata kunci: Photodioda, Sensor Sentuh(Touch), Mikrokontroler

(C) 2017 Elektron Jurnal Ilmiah

\section{I.PENDAHULUAN}

Pada zaman modern saat ini dan dipenuhi oleh berbagai kemajuan ilmu dan teknologi, setiap orang memiliki masing-masing kesibukan yang menyita waktu dan tenaga. Kegiatan pekerjaan dimulai dari pagi sampai sore hari, bahkan ada yang menjalani kegiatannya sampai malam hari. Kegiatan yang sama dilakukan dari hari ke hari yang membuat masing-masing orang mengalami tingkat kejenuhan yang tinggi terhadap pekerjaan yang mereka miliki.

Selain mengalami tingkat kejenuhan yang tinggi, masing-masing orang yang memiliki kegiatan yang banyak terhadap pekerjaannya juga mengalami kurangnya waktu kebersamaan bersama keluarga. Kebersamaan bersama keluarga pun akhirnya berkurang dan menimbulkan kurang harmonisnya hubungan sesama anggota keluarga. Pilihan liburan pada akhir minggu ataupun pada saat musim liburan pun menjadi pilihan untuk mengurangi tingkat kejenuhan yang dialami dalam pekerjaan sehari-hari sekaligus memperbaiki hubungan yang renggang selama menjalani hari-hari pekerjaan dan kembali meningkatkan hubungan harmonis sesama anggota keluarga.

Pada saat musim liburan maka setiap orang akan beramai-ramai berkunjung untuk menghabiskan waktu liburan mereka. Setiap tempat objek wisata biasanya akan di datangi oleh pengunjung secara beramai-ramai yang akan membuat pihak pengelola kewalahan dalam melayani pengunjung. Karena banyaknya pengunjung yang datang, pihak pengelola akan kesulitan dalam menghitung jumlah pengunjung. Selain menghitung jumlah pengunjung, pihak pengelola juga harus mengetahui berapa jumlah 
pengunjung yang masih di dalam tempat wisata dan yang telah keluar dari tempat wisata tersebut.

Pengelola tempat wisata harusnya mengetahui berapa orang yang masuk ke dalam tempat wisata yang dikelolanya dan berapa yang keluar serta berapa jumlah orang yang masih berada di dalam tempat wisata. Hal ini diperlukan agar pihak pengelola mengetahui, pada saat tempat wisata tersebut tutup apakah masih ada orang yang tertinggal di dalam atau adakah orang yang hilang di dalam area wisata tersebut.

Pada tempat parawisata konvensional pengunjung masuk hanya berdasarkan karcis. Setelah memiliki karcis maka pengunjung boleh masuk tanpa harus di hitung, dan hal inilah yang banyak mengakibatkan terjadinya insiden dimana pengunjung yang telat keluar setelah waktu tutup dari objek wisata tersebut. Kemudian pengunjung tersebut terkunci di dalam tempat wisata tanpa diketahui oleh pihak pengelola. Berdasarkan permasalahan diatas pada penelitian ini dikembangkan prototype penghitung jumlah pengunjung yang berada di dalam kebun binatang berbasis mikrokontroller. Tujuan dari penelitian ini adalah merancang dan membuat alat yang dapat menghitung jumlah pengunjung yang masuk serta keluar dari tempat wisata serta dapat mengefisisensi waktu. Penelitian terkait sebelumnya pernah dilakukan, Dhanar[1] membuat alat penghitung jumlah pengunjung toko, sensor ultrasonic SRF04 digunakan untuk mendeteksi pengunjung yang dating hasil pembacaan kemudian ditampilkan pada LCD. Menggunakan sensor infrared untuk mendeteksi pengunjung yang masuk pada ruangan terpadu di PLN I gusti agung.dkk[2] membuat alat untuk mendeteksi pengunjung, hasil pembacaan kemudian ditampilkan pada LCD. Dengan adanya alat ini diharapkan pengunjung lebih merasa aman dan nyaman dengan adanya pantauan dari pihak pengelola tempat wisata serta pengawas juga bisa memantau apakah semua pengunjung sudah keluar atau masih ada yang tertinggal di dalam area wisata. Hal ini mungkin juga dapat mengantisipasi jumlah pengunjung yang sangat banyak dengan cara menambahkan pintu gerbang tempat alat ini bekerja.

\section{METODE PENELITIAN}

Pada gambar 1 di bawah ini terlihat sebuah blok diagram yang menjelaskan fungsi satu- persatu fungsi sensor, serta display yang digunakan. Pada blok diagram di bawah juga menjelaskan masukan dan keluaran dari sistem mikrokontroler serta input dan output apa saja yang digunakan. Prototype alat penghitung jumlah pengunjung pada kebun binatang ini bekerja secara otomatis dengan dikontrol menggunakan arduino uno 328. Penghitungan jumlah pengunjung pada alat ini berdasarkan input dari 4 buah sensor yang mana dua buah sensor berfungsi untuk menghitung jumlah pengunjung yang masuk ke dalam area kebun binatang, sedangkan yang dua lagi menghitung jumlah pengunjung yang keluar dari area kebun binatang.

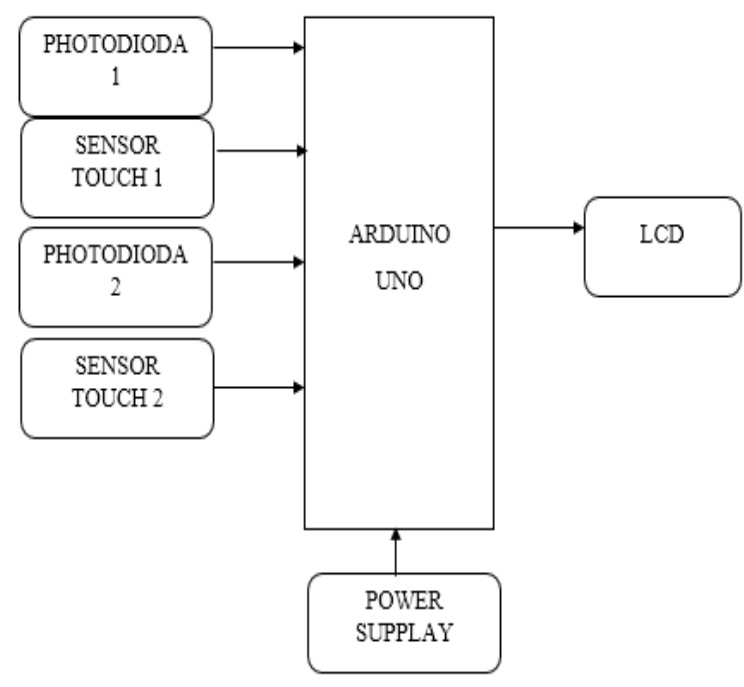

Gambar 1. Blok Diagram Prototype Penghitung Jumlah

Pengunjung Yang Berada Di Dalam Kebun Binatang

Dua buah sensor yang menghitung pengunjung yang masuk ke dalam area kebun binatang adalah photodioda 1 yang bekerja berdasarkan intensitas cahaya, jika cahaya yang di terima oleh potodioda berkurang maka akan mengirim signal ke arduino maka penghitunganya tambah 1 , dan juga sensor touch 1 yang berkerja berdasarkan adanya sentuhan pada permukaan sensor, sensor touch 1 berfungsi untuk menghitung ibu-ibu yang menggendong anak sehingga penghitunganya di tambah 1 , jadi jika ibuibu menggendong anak masuk maka setelah menekan sensor sentuh dan lewat dari photodioda maka akan otomatis penghitunganya menjadi dua. Prinsip kerja photodioada 2 dan sensor touch 2 juga sama seperti photodioda 1 dan sensor touch 1 , bedanya hanya photodioda 2 dan sensor touch 2 menghitung jumlah pengunjung yang keluar dari area kebun binatang. Sehingga ketika photodioda 2 atau sensor touch 2 mengirim sinyal ke arduino uno maka penghitungan yang ditampilkan pada layar LCD akan berkurang dengan rumus "jumlah pengunjung yang masuk - jumlah pengunjung yang keluar".

\subsection{Perancangan Hardware}

Perancangan hardware dari alat ini adalah Rangkaian elektronika, rangkaian yang terdiri dari sensor sentuh, Photodioda, Arduino, LCD dan rangkaian power supply yang dirangkai secara keseluruhan sehingga saling terhubung. Rangkaian keseluruhan prototype penghitung jumlah 
pengunjung yang berada di dalam kebun binatang bisa dilihat pada gambar 2 .

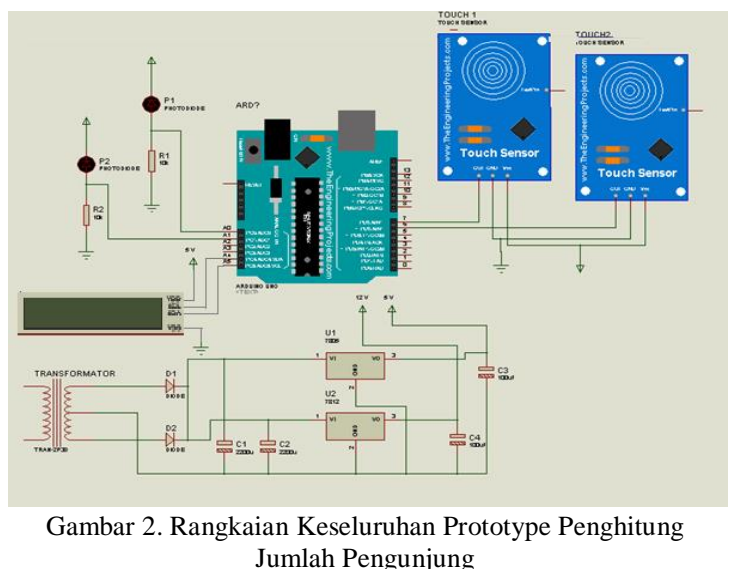

Power supply berguna untuk menjadi sumber tegangan yang masuk. Pada rangkaian power supply terdapat Trafo yang berguna untuk menurunkan dan megubah tegangan dari 220 VAC menjadi 12 VDC. Dioda berguna sebagai penyearah arus sebelum diberikan ke beban. Sedangkan kapasitor sebagai filter dan menyimpan tegangan dari input. IC regulator 7805 berfungsi menurunkan tegangan $+7,5$ VDC menjadi +5VDC. Dan IC regulator 7812 berfungsi untuk memfilter agar tegangan keluar tetap 12VDC. Photodioda adalah sebuah sensor cahaya yang bekerja berdasarkan pengaruh intensitas cahaya. Rangkaian sensor cahaya terdiri dari 3 buah pin yaitu pin untuk sumber atau positve 5VDC dan untuk ground, serta satu lagi untuk data yang berada antara negatif photodioda dan resisitor $10 \mathrm{Kohm}$, pin ini masuk ke pin 7 pada Arduino Uno. Sensor sentuh (touch sensor) adalah sensor yang bekerja berdasarkan sentuhan kulit makhluk hidup atau kulit manusia. Sensor sentuh memiliki 3 buah pin yang di antaranya pin 1 dan 2 berfungsi untuk sumber tegangan yaitu positif 5VDC dan pin ke-3 berfungsi sebagai data keluaran dari sensor sentuh yang akan di sambungkan ke pin 7 dan 6 pada Arduino Uno. LCD 16x2 digunakan sebagai penampil kondisi tinggi pintu air dan tinggi air aktif atau tidak. LCD dihubungkan ke pin Analog A4, A5 arduino, pin vec dan ground.

\subsection{Perancangan Software}

Flowchart proses kerja alat dapat dilihat pada gambar 3. Proses dimulai dari inisialisasi $I / O$, Selanjutnya pembacaan photodiode, jika pengunjung yang datang di deteksi oleh photodiode1, maka counter akan naik dan tampilan pada LCD jumlah pengunjung akan bertambah, sedangkan jika pengunjung yang datang di deteksi oleh photodiode2, maka counter akan turun dan tampilan pada LCD jumlah pengunjung akan berkurang. Begitu juga proses pada sensor touch.

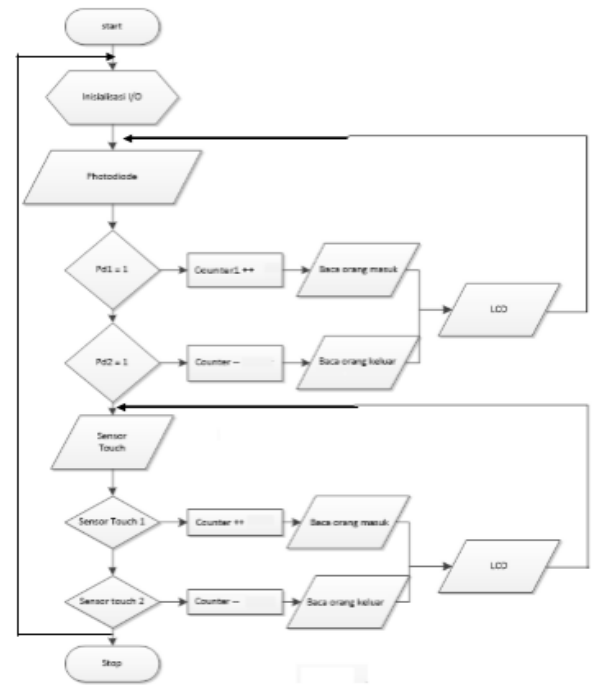

Gambar 3. Flowchart sistem penghitung jumlah pengunjung

\section{HASIL DAN PEMBAHASAN}

Pada bagian ini akan diperlihatkan hasil pengujian alat yang telah dibuat. Pertama pengujian sensor sentuh. Selanjutnya pengujian sensor photodiode Gambar 4 merupakan gambar alat secara keseluruhan.

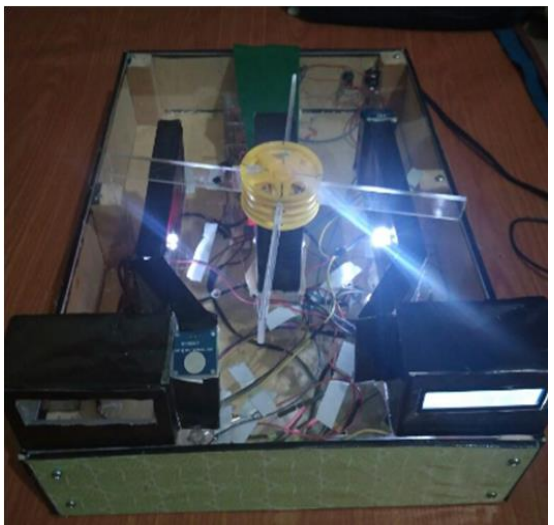

Gambar 4. Prototype Alat penghitung jumlah pengunjung di dalam kebun binatang

\subsection{Pengujian Dan Analisa Rangkaian Sensor Sentuh}

Rangkaian sensor sentuh merupakan rangkaian yang sederhana dimana sensor sentuh sudah berbentuk module sentuh yang hanya memiliki 3 keluaran yaitu data, Vcc dan ground. Pengujian diperlukan untuk mengetahui apakah sensor sentuh bekerja dengan baik atau tidak. Tabel 1 merupakan hasil pengukuran dari sensor sentuh

Tabel 1 merupakan hasil pengukuran dari sensor sentuh

\begin{tabular}{ccc}
\hline Keterangan & $\begin{array}{c}\text { Tegangan saat di } \\
\text { sentuh }\end{array}$ & $\begin{array}{c}\text { Tegangan saat tidak } \\
\text { di sentuh }\end{array}$ \\
\hline Sensor 1 & $4,84 \mathrm{~V}_{\mathrm{DC}}$ & $0,32 \mathrm{~V}_{\mathrm{DC}}$ \\
\hline Sensor 2 & $4,85 \mathrm{~V}_{\mathrm{DC}}$ & $0,32 \mathrm{~V}_{\mathrm{DC}}$ \\
\hline
\end{tabular}

Berdasarkan hasil pengukuran yang terdapat pada tabel di atas bahwa ketika sensor 1 di sentuh tegangan yang terukur pada data keluaran atau data 
masukan ke arduino uno sebesar 4,84 VDC. Sedangkan ketika sensor1 tidak di sentuh pengukuran pada data keluaran hanya sebesar 0,32 VDC. Ini membuktikan bahwa apabila sensor tidak di sentuh rangkaian yang terdapat di dalam rangkaian sensor sentuh tidak terhubung sehingga tidak terdapatnya tegangan, tetapi tegangan yang ada pada rangkaian tidak benar-benar terputus, tetapi masih tersisa tegangan yang kecil. Pengujian sensor 1 sama dengan sensor 2 begitu juga dengan hasil pengukuranya, hanya saja ada selisih 0,01 VDC pada tegangan di saat sensor di sentuh. Sensor sentuh bekerja berdasarkan logika aktif high, karena sensor sentuh akan bekerja ketika mendapatkan tegangan.

Untuk pembacaan sensor senuh pada arduino adalah, karena sensor sentuh hanya berlogika aktif high dan aktif low maka arduino hanya pemproses data 1 atau 0 . Jadi apabila sensor sentuh berlogika 1 maka arduino akan mengindikasikan bahwa ada pengunjung maka counter akan ditambah 1. Namun jika arduino membaca logika 0 maka arduino akan menginisialkan bahwa tidak ada pengunjung yang masuk atau melewati gerbang.

\subsection{Pengujian Dan Analisa Rangkaian Photodioda}

Rangkaian photodioda adalah rangkaian di mana photodioda hanya berdua dengan resistor untuk menjadi sebuah rangkaian sensor peka cahaya. Pengujian di perlukan untuk mengetahui apakah sensor peka terhadap cahaya atau tidak. Hasil pengujian rangkaian sensor photodiode dapat dilihat pada tabel 2.

Tabel 2. Hasil pengukuran dan pengujian sensor photodiode

\begin{tabular}{ccccc}
\hline Keterangan & $\begin{array}{c}\text { Ketika } \\
\text { Ada } \\
\text { Cahaya }\end{array}$ & $\begin{array}{c}\text { Ketika } \\
\text { Tidak } \\
\text { Ada } \\
\text { Cahaya }\end{array}$ & $\begin{array}{c}\text { ADC } \\
\text { ketika } \\
\text { ada } \\
\text { cahaya }\end{array}$ & $\begin{array}{c}\text { ADC } \\
\text { ketika } \\
\text { tidak ada } \\
\text { cahaya }\end{array}$ \\
\hline Photodioda 1 & $0,86 \mathrm{~V}_{\mathrm{DC}}$ & $43 \mathrm{mV}_{\mathrm{DC}}$ & $176 \mathrm{bit}$ & $9 \mathrm{bit}$ \\
\hline Photodioda 2 & $0,78 \mathrm{~V}_{\mathrm{DC}}$ & $47 \mathrm{mV} \mathrm{V}_{\mathrm{DC}}$ & $159 \mathrm{bit}$ & $10 \mathrm{bit}$ \\
\hline
\end{tabular}

Berdasarkan data yang tertera pada tabel di atas, dapat dilihat bahwa sensor cahaya atau photodioda sangat peka cahaya. Ketika photodioda 1 terkena cahaya maka resistansinya rendah sehingga tegangan yang dilewatkan menjadi tinggi, dari data yang di ambil pada photodioda 1 tegangan ketika terkena cahaya adalah 0,86 VDC, sedangkan ketika photodioda tidak terkena cahaya, atau pada situasi ini sama seperti ada sesuatu yang lewat di depan photo dioada nilai teganganya menjadi 0,043 VDC. Perhitunngan ini juga sama dengan photodioda 2 hanya saja nilai pengukurannya yang berbeda. Photodioda bekerja berdasarkan logika aktif low, karena photodioda akan bekerja di saat tegangan rendah atau hampir 0V. Arduino mengolah data hanya dengan bilangan biner yang terdiri dari logika 1 atau 0 , atau kalau tidak aktif high berarti aktif low.
Karna itu arduino menyediakan 6 buah pin khusus untuk pembacaan sensor yang outputnya analog. Di mana output sensor tersebut akan di konversi ke digital dengan ADC. Setelah mendapatkan nilai ADCnya maka akan dijadikan bilangan biner sebelum di proses oleh arduino. Dari nilai pencarian ADC di atas dapat dijadikan bilangan biner seperti tabel 3.

Tabel 3. Nilai biner dari bilangan ADC

\begin{tabular}{ccccccc}
\hline $2^{10}$ & $2^{9}$ & $2^{8}$ & $2^{7}$ & $2^{6}$ & $2^{5}$ & $2^{4}$ \\
\hline 0 & 0 & 0 & 1 & 0 & 1 & 0 \\
\hline 0 & 0 & 0 & 0 & 0 & 0 & 0 \\
\hline 0 & 0 & 0 & 1 & 0 & 0 & 1 \\
\hline 0 & 0 & 0 & 0 & 0 & 0 & 0 \\
\hline 1 & & & & & \\
\hline $2^{3}$ & $2^{2}$ & $2^{1}$ & $2^{0}$ & Nilai ADC \\
\hline 1 & 1 & 1 & 1 & $\begin{array}{c}\text { Pd 1 Saat ada } \\
\text { cahaya }=176\end{array}$ \\
\hline 1 & 0 & 0 & 1 & $\begin{array}{c}\text { Pd 1 Saat tidak ada } \\
\text { cahaya }=9\end{array}$ \\
\hline 1 & 1 & 1 & 1 & $\begin{array}{c}\text { Pd 2 Saat ada } \\
\text { cahaya = 159 }\end{array}$ \\
\hline 1 & 0 & 1 & 0 & $\begin{array}{c}\text { Pd 2 saat tidak ada } \\
\text { cahaya =10 }\end{array}$ \\
\hline
\end{tabular}

Dari tabel di atas dapat dilihat bahwa pada photodioda 1 ketika ada cahaya maka nilai biner yang terbaca oleh arduino adalah 00010101111. Sedangkan ketika tidak ada cahaya maka data yang dibaca oleh arduino adalah 00000001001. Ketika photodioda 2 mendapat cahaya maka data yang dibaca oleh arduino adalah 000101001111. Sedangkan ketika tidak mendapat cahaya data yang terbaca oleh arduino adalah 00000001001. Dari nilai tersebut dapat analisa bahwa pembacaan arduino pada photodioda 1 ketika ada cahaya adalah dengan bilangan biner 00010101111 yang berarti bahwa tidak ada pengunjung yang masuk atau melewati gerbang. Namun ketika photodioda mendapat cahaya maka data digital yang dikirim oleh photodioda ke aarduino setelah melalui ADC yaitu 00000001001 yang menginisialkan bahwa ada pengunjung yang melewati gerbang masuk. Sedangkan pada photodioda 2 akan mengirimkan data ADC 159bit yang apabila di binerkan menjadi 000101001111, jadi data biner inilah yang dibaca oleh arduino yang kemudian menginisialkan bahwa tidak ada pengunjung yang masuk atau melewati gerbang masuk. Apabila photodioda 2 tidak mendapat cahaya maka data ADC yang di dapat adalah 10bit yang apabila dibinerkan menjadi 00000001001, yang akan diinisialkan oleh arduino bahwa ada pengunjung yang masuk atau melewati gerbang masuk. 


\section{KESIMPULAN}

Setelah dilakukan pengambilan data dan percobaan alat secara langsung dapat diambil kesimpulan sebagai berikut :

1. Sensor sentuh 1 dan 2 berlogika aktif high dan akan berlogika aktif high apabila nilai tegangannya bernilai 4,84 - 4,85 Vdc, dan akan berlogika aktif low apabila tegangan nya bernilai $0,32 \mathrm{Vdc}$.

2. Photodioda 1 akan membaca pengunjung jika nilai pengukuran terbaca $43 \mathrm{mV}$ jika di ADC kan maka data ADC yang masuk ke arduino adalah 9bit, yang apabila dibinerkan menjadi 00000001001 data akan disimpan pada counter ++ sebagai penghitung jumlah pengunjung.

3. Photodioda 2 akan membaca pengunjung jika nilai pengukuran terbaca $47 \mathrm{mV}$ yang apabila di ADC kan maka data ADC yang masuk ke arduino adalah 10bit, yang apabila dibinerkan menjadi 00000001010 , data tersebut akan dimasukan ke counter -sebagai penghitung jumlah pengunjung yang keluar.

\section{REFERENSI}

[1] Dhanar Intan Surya Saputra. 2015. Rancang Bangun Alat Penghitung Jumlah Pengunjung di Toko Adhelina Berbasis Mikrokontroler Atmega 16. Jurnal SISFOKOM, Volume 04, Nomor 01, Maret 2015.

[2] I Gusti Agung Putu Raka Agung, I Made Irwan Susanto. 2012. Rancang Bangun Prototipe Penghitung Jumlah Orang Dalam Ruangan Terpadu Berbasis Mikrokontroler Atmega328. Majalah Ilmiah Teknologi Elektro Vol 11 No.1.2012

[3] Rico Dede Hardiyanto, Adian Faktur Rochim, Ike pertiwi Windasari.2015. Pembuatan Penghitung Mobil Otomatis Berbasis Mikrokontroler Atmega8535 Menggunakan Sensor Ultrasonic. Jurnal Teknologi dan Sistem Komputer, Vol.3, No.2, April 2015, hal: 185-191.

[4] Christoforus Yohannes. 2011. Sistem Penghitung Jumlah Barang Otomatis Dengan Sensor Ultrasonik. Jurnal Ilmiah "Elektrikal Enjiniring" UNHAS Volume 09/ No.02/Mei Agustus/ 2011, hal: 66-71.

[5] Albar, Zainal Abidin, Tuti Anggraini,2009. Pengontrolan Pergerakan Robot Penelusuran Lintasan Menggunakan Metode Kontrol Logika Fuzzy, Padang: Poli Rekayasa Volume 4.

[6] Dia, Septi Ayu,2014. Rancang Bangun Miniatur Sistem Buka Tutup Pintu Keluar Portal Parkiran Kendaraan Bermotor Dengan Input Koin Berbasis Programable Logic Device (PLD). Laporan Tugas Akhir : Politeknik Negeri Padang.

[7] Gunawa, Jefri,2015. Alat Penghitung Jumlah Pengunjung Dalam Ruangan Pertunjukan Berbasis Mikrokontroller Dengan Tampilan Lcd Dan Pc (Personal Komputer). Laporan Tugas Akhir : Politeknik Negeri Padang. 